\title{
Integrated crop pollination to buffer spatial and temporal variability in pollinator activity
}

Article

Accepted Version

Creative Commons: Attribution-Noncommercial-No Derivative Works 4.0

Garratt, M. P. D., Brown, R., Hartfield, C., Hart, A. and Potts, S. G. (2018) Integrated crop pollination to buffer spatial and temporal variability in pollinator activity. Basic and Applied Ecology, 32. pp. 77-85. ISSN 1439-1791 doi: https://doi.org/10.1016/j.baae.2018.06.005 Available at https://centaur.reading.ac.uk/77941/

It is advisable to refer to the publisher's version if you intend to cite from the work. See Guidance on citing.

To link to this article DOI: http://dx.doi.org/10.1016/j.baae.2018.06.005

Publisher: Elsevier

All outputs in CentAUR are protected by Intellectual Property Rights law, including copyright law. Copyright and IPR is retained by the creators or other copyright holders. Terms and conditions for use of this material are defined in the End User Agreement.

www.reading.ac.uk/centaur 
Central Archive at the University of Reading

Reading's research outputs online 


\section{Accepted Manuscript}

Title: Integrated crop pollination to buffer spatial and temporal variability in pollinator activity

Authors: Michael P.D. Garratt, Rob Brown, Chris Hartfield, Alan Hart, Simon G. Potts

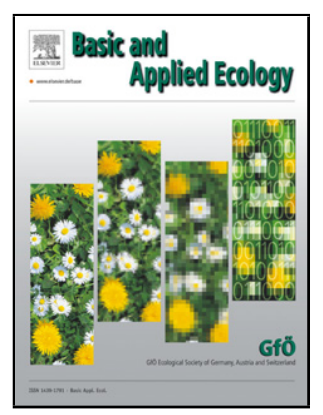

PII:

S1439-1791(18)30007-0

DOI: https://doi.org/10.1016/j.baae.2018.06.005

Reference: BAAE 51125

To appear in:

Received date: $\quad 8-1-2018$

Revised date: 20-6-2018

Accepted date: $\quad$ 21-6-2018

Please cite this article as: Garratt, Michael PD., Brown, Rob., Hartfield, Chris., Hart, Alan., and Potts, Simon G., Integrated crop pollination to buffer spatial and temporal variability in pollinator activity.Basic and Applied Ecology (2018), https://doi.org/10.1016/j.baae.2018.06.005

This is a PDF file of an unedited manuscript that has been accepted for publication. As a service to our customers we are providing this early version of the manuscript. The manuscript will undergo copyediting, typesetting, and review of the resulting proof before it is published in its final form. Please note that during the production process errors may be discovered which could affect the content, and all legal disclaimers that apply to the journal pertain. 


\title{
Integrated crop pollination to buffer spatial and temporal
}

\section{variability in pollinator activity}

Michael P. D. Garratt ${ }^{\mathrm{a}^{*}}$ m.p.garratt@reading.ac.uk, Rob Brown ${ }^{\mathrm{a}}$, Chris Hartfield ${ }^{\mathrm{b}}$, Alan Hart ${ }^{\mathrm{c}}$ and Simon

G. Potts ${ }^{a}$

${ }^{a}$ Centre for Agri-Environmental Research, School of Agriculture, Policy and Development, University of Reading, Reading, RG6 6AR, UK.

${ }^{\mathrm{b}}$ National Farmers Union, Agriculture House, Stoneleigh Park, Stoneleigh, Warwickshire, CV8 2TZ

'Bee Farmers Association, West Totton, Southampton, Hampshire S040 8FH

*Corresponding author. Tel.: +44 (0)1183786149.

\begin{abstract}
Insect pollination improves the yield and quality of many crops, yet there is increasing evidence of insufficient insect pollinators limiting crop production. Effective Integrated Crop Pollination (ICP) involves adaptable, targeted and cost effective management of crop pollination and encourages the use of both wild and managed pollinators where appropriate. In this study we investigate how the addition of honeybee hives affects the community of insects visiting oilseed rape, and if hive number and location affect pollinator foraging and oilseed rape pollination in order to provide evidence for effective ICP. We found that introducing hives increased overall flower visitor numbers and altered the pollinator community, which became dominated by honeybees. Furthermore a greater number of hives did not increase bee numbers significantly but did result in honeybees foraging further into fields. The timing of surveys and proximity to the field edge influenced different pollinators in different
\end{abstract}


ways and represents an example of spatial and temporal complementarity. For example dipteran flower visitor numbers declined away from the field edge whereas honeybees peaked at intermediate distances into the field. Furthermore, no significant effects of survey round on wild bees overall was observed but honeybee numbers were relatively lower during peak flowering and dipteran abundance was greater in later survey rounds. Thus combining diverse wild pollinators and managed species for crop pollination buffers spatial and temporal variation in flower visitation. However we found no effect of insect pollination on seed set or yield of oilseed rape in our trial, highlighting the critical need to understand crop demand for insect pollination before investments are made in managing pollination services.

\section{Keywords:}

Crop pollination, Brassica napus, honeybee, wild pollinators, oilseed rape

\section{Introduction}

Insect pollinators are crucial for global food production, making important contributions to yield and quality of many crops (Klein et al., 2007; Kleijn et al., 2015). However, both managed and wild pollinator populations are under threat from multiple pressures and this can impact on the crop pollination services they provide (Vanbergen \& Initiative, 2013; Potts et al., 2016). To support sufficient pollination of many crops, managed pollinators are utilised in increasing numbers (Rucker et al., 2012). At the same time, the important contribution to crop pollination of a diversity of wild pollinators is becoming increasingly well understood (Garibaldi et al., 2013; Garibaldi et al., 2016; Rader et al., 2016). As global demand for insect-pollinated crops continues to rise (Aizen et al., 2008) and incidents of insufficient insect pollination limiting crop production are increasingly documented (Holzschuh et al., 2012; Button \& Elle, 2014; Garratt et al., 2014a) it is necessary to find effective means to match pollinator supply to pollination demand and counter any deficits. 
The ability to effectively utilise both wild pollinators and managed species represents the best opportunity to provide sufficient and stable pollination services to crops (Rader et al., 2012; Brittain et al., 2013b; Garibaldi et al., 2014) as well as the opportunity to fill short-term pollination deficits if necessary. Adaptable, targeted and cost effective management of pollinators for crops can be captured by the concept of Integrated Crop Pollination (ICP) (Isaacs et al., 2017). Effective ICP requires a solid evidence base, including an understanding of a crop's demand for insect pollination, the potential contribution of wild pollinators and the optimal management strategy for utilising managed species if required.

Oilseed rape (Brassica napus) is a crop of global importance and the area being grown is increasing year on year (Breeze et al., 2014). Many varieties of oilseed rape benefit from insect pollination, which can increase pod set and seed set, and improve crop quality (Bommarco et al., 2012; Hudewenz et al., 2013; Garratt et al., 2014b). Across the world, oilseed rape is visited by a diverse pollinator community which includes honeybees (Apis mellifera), solitary bees and bumblebees (Bombus spp.) as well as flies and other pollinators (Rader et al., 2009; Ali et al., 2011; Stanley et al., 2013; Woodcock et al., 2013; Garratt et al., 2014b). Honeybees are also used to supplement the pollination of oilseed rape, with resulting improvements to yield (Manning \& Wallis, 2005; Sabbahi et al., 2005; Witter et al., 2014).

In the UK, oilseed rape is a widely grown crop that is an integral part of arable rotations across the country (Breeze et al., 2014). The insect community visiting oilseed rape in the UK is diverse and includes many groups of species but this is known to vary from field to field and the effectiveness of flower visitors as pollinators depends on taxonomic group (Woodcock et al., 2013; Garratt et al., 2014b). Honeybees are not widely used to supplement oilseed rape pollination in the UK, probably due to the large areas grown (Breeze et al., 2011), their potential contribution to production is not well understood and the optimal management with regards to stocking densities and foraging behaviour is not well characterised. 
To provide evidence to underpin effective ICP of oilseed rape in the UK, this study aimed to 1) investigate how the addition of honeybee hives affects the community of insects visiting oilseed rape flowers, 2) understand how hive number and hive location affects honeybee foraging on oilseed rape and 3) quantify how provision of honeybee hives affects oilseed rape pollination and production.

\section{Materials and methods}

\section{Field sites}

Nine conventionally managed fields of oilseed rape (variety Picto) were selected in the counties of Gloucestershire and Herefordshire in the UK in spring 2015. Fields were located in three study blocks so that each block was made up of three fields. One field in each block had 10 honeybee hives placed on an accessible field margin adjacent to the field. A second field in each block had 30 honeybee hives placed on an adjacent field margin and the remaining field acted as a control with the addition of no hives (Fig. 1). Honeybee hives were placed out at study fields at the onset of oilseed rape flowering and were removed after flowering had finished. Study field sizes were typical of the region with a mean area of 8.4 ha ( $S E \pm 1.6$ ). Mean equivalent stocking density was 1.7 ( $S E \pm 0.29$ ) hives per hectare for fields with 10 hives introduced and 2.7 (SE \pm 0.64 ) hives per hectare for fields with 30 hives. Study fields were not adjacent to any other oilseed rape fields and fields were at least $2 \mathrm{~km}$ apart.

\section{Pollinator surveys}

Pollinator surveys were carried out in a study plot measuring $75 \mathrm{~m}$ by $75 \mathrm{~m}$ adjacent to the field margin in each study field. During April 2015, three rounds of pollinator surveys were carried out in each field. Surveys were done in conditions with temperatures in excess of $13{ }^{\circ} \mathrm{C}$, low wind and no rain, and all fields within a block were visited on the same day and the order in which fields were visited in each block was different for each survey round. A pollinator survey involved walking four, 15-minute, 75-m transects parallel to the field edge in each study plot along crop tramlines; where the vehicle wheelings are located. During transect walks, all insect visitors to oilseed rape flowers were recorded 
to broad taxonomic group in a $2 \mathrm{~m}$ by $2 \mathrm{~m}$ moving observation window to one side of the observer. The first transect was walked along the field edge, adjacent to the control field margin or field margin with honeybee hives. The second transect was walked along the first tramline in from the field edge (c. $20 \mathrm{~m}$ from the field edge) and the third and fourth were along the second $(c .40 \mathrm{~m})$ and third $(c .60$ m) tramlines. At two sites where the tramlines were not parallel to the field edge, each transect was divided into three $25 \mathrm{~m}$ subsections. These subsections were located in the perpendicular tramlines with their centre point at distances from the field edge equivalent to that for surveys where the tramlines were paralleled to the field edge. Thus pollinator data collected from fields with both tramline orientations was directly comparable.

\section{Pollination service measures}

To measure the effects of insect pollination on oilseed rape yield, two study plants were selected at least one metre apart and in the middle of each of the four pollinator transects in each study plot. At the onset of flowering, one plant in each pair was enclosed within a large $(1 \mathrm{~m}$ by $30 \mathrm{~cm})$ nylon pollinator exclusion bag ( $1.33 \mathrm{~mm}$ gauge size) to prevent access to the flowers by insects but allow wind and self-pollination (Bagged plants). The other plant in each pair acted as a control (Open plants). During flowering the study plants were visited regularly and the bags were adjusted as the plants grew so only open flowers were covered and to minimise any effects of the bag on plant growth. At the end of flowering the bag was removed. Just prior to harvest in each field, study plants were collected and the number of pods on each plant was counted, the number of seeds per pod from five randomly selected pods was then determined before the plants were threshed to establish plant yield.

\section{Analysis}

Generalised linear mixed effects models using the 'glmer' function in the 'Ime4' package were used to investigate the effects of introducing hives, pollinator taxa and their interaction on the number of visitors observed on transects. Field, nested within block, as well as survey round were included as random effects and a Poisson error structure was defined because data were counts. The 'drop1' 
function was used to select the minimum adequate model and generate statistical outputs using the likelihood ratio test. A significant interactive effect of hive number and pollinator group was found and to interpret this, Tukey contrasts using the 'multcomp' package were carried out with each hive number and pollinator taxon combination as a separate factor level in the model.

To investigate the effects of hive number, distance from the field edge and their interaction on number of honeybees visiting, a generalised linear mixed effects model was used with a Poisson error structure and the same random effects as for previous models. Again the likelihood ratio test found a significant hive number:distance interaction and so Tukey contrasts were used to determine significant difference between factor levels.

Generalised linear mixed effects models were also used to investigate the effects of distance from the field edge, survey round and their interaction on foraging by different pollinator taxa with the same random effects as before. Distance and survey round were treated as categorical variables. Due to some low counts and to improve model fit, counts of solitary bees and bumblebees were combined to create a wild bee group, and hoverflies and other Diptera were combined to create a Diptera group. Again Tukey contrasts were used to interpret significant effects.

Using the linear mixed effect models function 'Imer' in the 'Ime4' package, pollination (seeds per pod and pods per plant) and yield (grams per plant) of bagged vs. open plants was compared as well as the effect of hive number and distance into the field and their two way interactions. Field nested within block were included as random effects. Yield in grams and pods per plant were log-transformed prior to analyses. All analysis were carried out in $\mathrm{R}$ version 3.3 .2

\section{Results}

Hoverflies and other Diptera, honeybees, bumblebees, solitary bees, moths and butterflies were all observed visiting oilseed rape flowers. Non-hoverfly Diptera, followed by hoverflies, were the most abundant wild visitors and the placement of honeybee hives at the edge of oilseed rape fields altered 
the pollinator community visiting crop flowers considerably (Fig. 2), primarily by increasing the number of honeybee visitors. There was a significant interactive effect of hive number and pollinator taxonomic group on the number of floral visitors observed during transects $\left(\mathrm{df}=10, \chi^{2}=243.8, p<\right.$ 0.001). In the absence of honeybee hives, non-hoverfly Diptera were the most common flower visitors, with significantly more visitors observed than all other pollinator groups $(z>5.26, p<0.01)$. The number of hoverflies was also significantly greater than bumblebees, honeybees and Lepidoptera $(z>4.09, p<0.01)$. When 10 honeybee hives were placed adjacent to a field, honeybees were the most common flower visitor, with significantly more visitors observed than all other pollinator groups $(z>5.85, p<0.05)$. Non-hoverfly Diptera were also more abundant than all other groups $(z>5.66, p$ $<0.01$ ) except honeybees. When 30 hives were placed at the field edge, again honeybees were by far the most abundant flower visitor compared to all other pollinator groups $(z>7.67, p<0.05)$ and nonhoverfly Diptera were more abundant than other wild pollinators $(z>6.08, p<0.05)$. Although the total number of all flower visitors was affected by the introduction of hives ( $d f=2, \chi^{2}=13.31, p<$ $0.001)$ with significantly more seen per transects at sites with 10 (10.7 \pm SD 5.6) and 30 (11.8 \pm SD 6.4) hives compared to no hives $(5.2 \pm$ SD 4.2$)(z>3.75,=<0.01)$, only the number of honeybees was significantly affected $(z>9.24=<0.001)$. The abundance of other pollinator groups neither increased nor decreased significantly following the introduction of hives.

There was a significant interactive effect of hive number and distance into the field on the number of honeybees observed on transects ( $d f=6, \chi^{2}=36.95, p<0.001$ ) (Fig. 3). At the field edge, the number of honeybees observed in fields with 10 hives was greater than for fields with 30 hives or no hives (z $>3.27, p<0.035)$. The number of honeybee visitors observed was greater for fields with 10 or 30 hives compared to fields with no hives, at $20 \mathrm{~m}(z>5.47, p<0.001)$ and at $40 \mathrm{~m}(z>4.20, p<0.05)$. At $60 \mathrm{~m}$ into the field, the number of visitors observed was greater for fields with 10 or 30 hives compared to those with no hives $(z>3.19, p<0.044)$ but the number of visitors was also greater in fields with 30 hives compared to those with $10(z=3.71, p<0.01)$. 
Distance from the field edge significantly affected the number of visitors observed on transects for both Diptera and honeybees (Table 1) (Fig. 4). The number of honeybees was greater at $20 \mathrm{~m}$ and 40 $m$ compared to both $0 \mathrm{~m}(z=3.98, p<0.001)$ and $60 \mathrm{~m}(z<3.56, p<0.01)$. For Diptera, the number of visitors at the field edge was greater than for all other distances $(z>3.02, p<0.05)$. There was no significant effect of distance on wild bee visitors although a significant distance:round interaction was found. The number of floral visitors observed on transects was affected by survey round for honeybees and Diptera (Table 1) (Fig. 5). The number of honeybees visiting flowers was significantly fewer on the second survey round when compared to the first and third round $(z>2.79, P<0.014)$ and the number of Diptera recorded on surveys was significantly less on survey round one compared to rounds two and three $(z>6.82, p<0.001)$.

There was no significant interaction or main effect on yield of pollination treatment (open vs. bagged plants) ( $\left.d f=1, \chi^{2}=0.039, P=0.84\right)$, distance from the field edge $\left(d f=3, \chi^{2}=3.12, P=0.37\right.$ ) or hive number $\left(d f=2, \chi^{2}=1.04, P=0.59\right.$ ) (Supp Table). Similarly no effect of pollination treatment $\left(d f=1, \chi^{2}\right.$ $=0.024, P=0.88)$, distance $\left(d f=3, \chi^{2}=7.19, P=0.066\right)$ or hive number $\left(d f=2, \chi^{2}=2.64, P=0.27\right)$ was seen on seeds per pod or an effect of pollination treatment $\left(d f=1, \chi^{2}=0.33, P=0.57\right)$, distance $(d f=$ $\left.3, \chi^{2}=2.20, P=0.53\right)$ or hive number $\left(d f=2, \chi^{2}=0.80, P=0.67\right)$ on pods per plant.

\section{Discussion}

Diverse insect pollinator communities were observed visiting oilseed rape flowers, and introducing honeybee hives to the edge of fields considerably increased the number of flower visitors and altered the pollinator community which became dominated by honeybees. Furthermore, the introduction of a greater number of hives was associated with an increase in honeybees foraging further into the field while numbers at the field edge were reduced. We found that proximity to the field edge and survey round influenced taxonomic groups of flower visiting insects in different ways and this represents an example of functional complementarity (Hoehn et al., 2008; Blüthgen \& Klein, 2011). Thus combining 
diverse wild pollinators and managed species buffers spatial and temporal variation in flower visitation.

Introducing honeybee hives to the edge of oilseed rape fields increased the number of honeybees visiting oilseed rape flowers so that they became the dominant taxonomic group, contributing more than $50 \%$ of all observed visitors, compared to less than $5 \%$ in the absence of hives. This supports the conclusion that using honeybees can be an option to increase pollination of oilseed rape (Manning \& Wallis, 2005; Sabbahi et al., 2005; Witter et al., 2014). In terms of optimising this pollination, there was no increase in the number of visitors overall following the introduction of 30 compared to 10 hives, but a significant increase at $60 \mathrm{~m}$ in field with 30 hives shows a potential benefit of introducing more than 10 hives with bees foraging further into the field.

The impact of survey round and proximity to the field edge had distinctly contrasting effects on different pollinator taxa. A component of the wild pollinator community, namely the Diptera, declined steadily away from the field edge, whilst honeybee activity peaked at $20 \mathrm{~m}$ and $40 \mathrm{~m}$ into the field. This is driven by their foraging behaviour and contrasting edge effects on pollinators have been observed in other studies (Bailey et al., 2014; Woodcock et al., 2016). This demonstrates that a diverse community of pollinators, which includes honeybees, is more likely to ensure pollination across the field and buffer different species responses to the field edge. Although UK arable fields can be large, any point in the field will rarely be more than $80 \mathrm{~m}$ from any edge, therefore ensuring provision of adequate pollination services up to this distance, covers the vast majority of a field.

The variation in flower visitor activity seen between survey rounds in this study could be driven by a number of factors, including differing responses to weather on the day of surveys (Brittain et al., 2013a), competition with other flowering crops in the landscape (Holzschuh et al., 2016) or changes in floral resource availability and pollinator activity over the flowering cycle of the crop (Mesa et al., 2013). Interestingly, we found distinctly contrasting effects of survey round on the three groups of pollinators tested. Activity of Diptera was lower during early flowering compared to honeybees, which 
were most active in survey round one and three. The activity of wild bees by contrast was not significantly affected by survey round, probably because this is a particularly diverse group with different species responding in different ways. Nonetheless this demonstrates clear complementarity between groups, and to ensure good flower visitation throughout crop flowering, abundant communities of multiple taxa would be beneficial.

The distribution of different flower visiting insects in space and time within a crop field may be a result of interactions between species and there is concern that honeybees may displace wild flower visitors in some instances (Geldmann \& González-Varo, 2018), although facilitative benefits to pollination following interactions between honeybees and other pollinators have also been reported (Greenleaf \& Kremen, 2006). In this study, despite a nearly 30 -fold increase in the number of honeybees recorded in fields with 30 hives compared to no-hive controls, the abundance of other taxa was not affected, indicating no strong interactions between different groups of flower visitors.

We found no effect of introducing honeybees or proximity to the field edge on pollination or production of oilseed rape, and importantly pollinator exclusion treatments had no detectable effect on pollination or yield. The variety of oilseed used in this study was Picto, which is a conventional variety becoming increasingly common in the UK. The dependence of oilseed rape on out-crossing and pollen movement within flowers varies considerably between varieties with the contribution of insect pollinators to yield estimated at anywhere between 0 and 50\% (Williams et al., 1986; Sabbahi et al., 2005; Bommarco et al., 2012; Hudewenz et al., 2013) and it may be that this variety benefits little from insect pollination. Alternatively it may be that pollinator activity was relatively low in this study, particularly for those species of wild bee which are known to be particularly effective pollinators of oilseed (Woodcock et al., 2013; Garratt et al., 2014b) and so no effect of pollinator exclusion was observed. However, honeybees do improve pollination and yield in some oilseed varieties (Manning \& Wallis, 2005; Lindström et al., 2016) yet the high numbers observed in this study still did not elicit a clear response. 
In this study we did not measure the crop quality parameters of oil content or chlorophyll content so there may be other effects of insect pollination not detected. Breeding parthenocapy into crop varieties could reduce dependence on pollination (Knapp et al., 2017) and be part of an integrated pollination strategy. However, recent studies on oilseed rape demonstrate the benefits of insect pollination in many varieties (Manning \& Wallis, 2005; Bommarco et al., 2012; Jauker et al., 2012) and even single visits to flowers by some taxa result in increased seed set (Garratt et al., 2014b). This highlights the critical need to first understand the dependence of a crop on insect pollination before investment is made in pollination services, although the wider benefits of a diverse pollinator community for wild plant reproduction in agricultural landscapes should also be considered (Ollerton et al., 2011).

This study demonstrates how utilising both wild and managed pollinators as part of ICP could buffer spatial and temporal influences on pollinator activity and ensure a consistent supply of flower visitors in a key mass-flowering crop. It also highlights the critical need to understand the insect pollinator dependence of a crop and the potential economic benefits or not of pollination before investments are made in pollination services. However, the dependence of all crops and varieties grown in a landscape, as well as wild plant communities dependent on insect pollination, and the benefits to beekeepers in the form of pollen and nectar provision for hives, must also be taken into account.

\section{Acknowledgements}

We would like to thank the beekeepers of the UK Bee farmers Associations for providing hives and valuable expertise for this study. We would also like to thank the farmers for allowing us to carry out fieldwork on their land as well as their enthusiastic support for the project. This work was funded via the EU FP7 project LIBERATION (grant 311781) and supported by the Super B Sustainable Pollination in Europe EU COST action project.

\section{Reference}

Aizen, M.A., Garibaldi, L.A., Cunningham, S.A., Klein, A.M., 2008. Long-Term Global Trends in Crop Yield and Production Reveal No Current Pollination Shortage but Increasing Pollinator Dependency. Current Biology 18, 1572-1575. 
Ali, M., Saeed, S., Sajjad, A., Whittington, A., 2011. In search of the best pollinators for canola (Brassica napus L.) production in Pakistan. Applied Entomology and Zoology 46, 353-361.

Bailey, S., Requier, F., Nusillard, B., Roberts, S.P.M., Potts, S.G., Bouget, C., 2014. Distance from forest edge affects bee pollinators in oilseed rape fields. Ecology and Evolution 4, 370-380.

Blüthgen, N., Klein, A.-M., 2011. Functional complementarity and specialisation: The role of biodiversity in plant-pollinator interactions. Basic and Applied Ecology 12, 282-291.

Bommarco, R., Marini, L., Vaissiere, B.E., 2012. Insect pollination enhances seed yield, quality, and market value in oilseed rape. Oecologia 169, 1025-1032.

Breeze, T.D., Bailey, A.P., Balcombe, K.G., Potts, S.G., 2011. Pollination services in the UK: How important are honeybees? Agriculture, Ecosystems \& Environment 142, 137-143.

Breeze, T.D., Vaissière, B.E., Bommarco, R., Petanidou, T., Seraphides, N., Kozák, L., Scheper, J., Biesmeijer, J.C., Kleijn, D., Gyldenkærne, S., Moretti, M., Holzschuh, A., Steffan-Dewenter, I., Stout, J.C., Pärtel, M., Zobel, M., Potts, S.G., 2014. Agricultural policies exacerbate honeybee pollination service supply-demand mismatches across Europe. PLOS ONE 9, e82996.

Brittain, C., Kremen, C., Klein, A.M., 2013a. Biodiversity buffers pollination from changes in environmental conditions. Global Change Biology 19, 540-547.

Brittain, C., Williams, N., Kremen, C., Klein, A.-M., 2013b. Synergistic effects of non-Apis bees and honey bees for pollination services. Proceedings of the Royal Society Biological Sciences Series B 280, 1-7.

Button, L., Elle, E., 2014. Wild bumble bees reduce pollination deficits in a crop mostly visited by managed honey bees. Agriculture, Ecosystems \& Environment 197, 255-263.

Garibaldi, L.A., Carvalheiro, L.G., Leonhardt, S.D., Aizen, M.A., Blaauw, B.R., Isaacs, R., Kuhlmann, M., Kleijn, D., Klein, A.M., Kremen, C., Morandin, L., Scheper, J., Winfree, R., 2014. From research to action: enhancing crop yield through wild pollinators. Frontiers in Ecology and the Environment 12, 439-447. Garibaldi, L.A., Carvalheiro, L.G., Vaissière, B.E., Gemmill-Herren, B., Hipólito, J., Freitas, B.M., Ngo, H.T., Azzu, N., Sáez, A., Åström, J., An, J., Blochtein, B., Buchori, D., García, F.J.C., Oliveira da Silva, F., Devkota, K., Ribeiro, M.d.F., Freitas, L., Gaglianone, M.C., Goss, M., Irshad, M., Kasina, M., Filho, A.J.S.P., Kiill, L.H.P., Kwapong, P., Parra, G.N., Pires, C., Pires, V., Rawal, R.S., Rizali, A., Saraiva, A.M., Veldtman, R., Viana, B.F., Witter, S., Zhang, H., 2016. Mutually beneficial pollinator diversity and crop yield outcomes in small and large farms. Science 351, 388-391.

Garibaldi, L.A., Steffan-Dewenter, I., Winfree, R., Aizen, M.A., Bommarco, R., Cunningham, S.A., Kremen, C., Carvalheiro, L.G., Harder, L.D., Afik, O., Bartomeus, I., Benjamin, F., Boreux, V., Cariveau, D., Chacoff, N.P., Dudenhöffer, J.H., Freitas, B.M., Ghazoul, J., Greenleaf, S., Hipólito, J., Holzschuh, A., Howlett, B., Isaacs, R., Javorek, S.K., Kennedy, C.M., Krewenka, K.M., Krishnan, S., Mandelik, Y., Mayfield, M.M., Motzke, I., Munyuli, T., Nault, B.A., Otieno, M., Petersen, J., Pisanty, G., Potts, S.G., Rader, R., Ricketts, T.H., Rundlöf, M., Seymour, C.L., Schüepp, C., Szentgyörgyi, H., Taki, H., Tscharntke, T., Vergara, C.H., Viana, B.F., Wanger, T.C., Westphal, C., Williams, N., Klein, A.M., 2013. Wild Pollinators Enhance Fruit Set of Crops Regardless of Honey Bee Abundance. Science 339, 1608-1611.

Garratt, M.P.D., Breeze, T.D., Jenner, N., Polce, C., Biesmeijer, J.C., Potts, S.G., 2014a. Avoiding a bad apple: Insect pollination enhances fruit quality and economic value. Agriculture, Ecosystems \& Environment 184, 34-40.

Garratt, M.P.D., Coston, D.J., Truslove, C.L., Lappage, M.G., Polce, C., Dean, R., Biesmeijer, J.C., Potts, S.G., 2014b. The identity of crop pollinators helps target conservation for improved ecosystem services(). Biological Conservation 169, 128-135.

Geldmann, J., González-Varo, J.P., 2018. Conserving honey bees does not help wildlife. Science 359, 392-393.

Greenleaf, S.S., Kremen, C., 2006. Wild bees enhance honey bees' pollination of hybrid sunflower. Proceedings of the National Academy of Sciences of the United States of America 103, 13890-13895. Hoehn, P., Tscharntke, T., Tylianakis, J.M., Steffan-Dewenter, I., 2008. Functional group diversity of bee pollinators increases crop yield. Proceedings of the Royal Society B-Biological Sciences 275, 22832291. 
Holzschuh, A., Dainese, M., González-Varo, J.P., Mudri-Stojnić, S., Riedinger, V., Rundlöf, M., Scheper, J., Wickens, J.B., Wickens, V.J., Bommarco, R., Kleijn, D., Potts, S.G., Roberts, S.P.M., Smith, H.G., Vilà, M., Vujić, A., Steffan-Dewenter, I., 2016. Mass-flowering crops dilute pollinator abundance in agricultural landscapes across Europe. Ecology Letters 19, 1228-1236.

Holzschuh, A., Dudenhöffer, J.-H., Tscharntke, T., 2012. Landscapes with wild bee habitats enhance pollination, fruit set and yield of sweet cherry. Biological Conservation 153, 101-107.

Hudewenz, A., Pufal, G., Bogeholz, A.-L., Klein, A.-M., 2013. Cross-pollination benefits differ among oilseed rape varieties. The Journal of Agricultural Science FirstView, 1-9.

Isaacs, R., Williams, N., Ellis, J., Pitts-Singer, T.L., Bommarco, R., Vaughan, M., 2017. Integrated Crop Pollination: Combining strategies to ensure stable and sustainable yields of pollination-dependent crops. Basic and Applied Ecology 22, 44-60.

Jauker, F., Bondarenko, B., Becker, H.C., Steffan-Dewenter, I., 2012. Pollination efficiency of wild bees and hoverflies provided to oilseed rape. Agricultural and Forest Entomology 14, 81-87.

Kleijn, D., Winfree, R., Bartomeus, I., Carvalheiro, L.G., Henry, M., Isaacs, R., Klein, A.-M., Kremen, C., M'Gonigle, L.K., Rader, R., Ricketts, T.H., Williams, N.M., Lee Adamson, N., Ascher, J.S., Baldi, A., Batary, P., Benjamin, F., Biesmeijer, J.C., Blitzer, E.J., Bommarco, R., Brand, M.R., Bretagnolle, V., Button, L., Cariveau, D.P., Chifflet, R., Colville, J.F., Danforth, B.N., Elle, E., Garratt, M.P.D., Herzog, F., Holzschuh, A., Howlett, B.G., Jauker, F., Jha, S., Knop, E., Krewenka, K.M., Le Feon, V., Mandelik, Y., May, E.A., Park, M.G., Pisanty, G., Reemer, M., Riedinger, V., Rollin, O., Rundlof, M., Sardinas, H.S., Scheper, J., Sciligo, A.R., Smith, H.G., Steffan-Dewenter, I., Thorp, R., Tscharntke, T., Verhulst, J., Viana, B.F., Vaissiere, B.E., Veldtman, R., Westphal, C., Potts, S.G., 2015. Delivery of crop pollination services is an insufficient argument for wild pollinator conservation. Nat Commun 6.

Klein, A.-M., Vaissière, B.E., Cane, J.H., Steffan-Dewenter, I., Cunningham, S.A., Kremen, C., Tscharntke, T., 2007. Importance of pollinators in changing landscapes for world crops. Proceedings of the Royal Society B: Biological Sciences 274, 303-313.

Knapp, J.L., Bartlett, L.J., Osborne, J.L., 2017. Re-evaluating strategies for pollinator-dependent crops: How useful is parthenocarpy? Journal of Applied Ecology 54, 1171-1179.

Lindström, S.A.M., Herbertsson, L., Rundlöf, M., Smith, H.G., Bommarco, R., 2016. Large-scale pollination experiment demonstrates the importance of insect pollination in winter oilseed rape. Oecologia 180, 759-769.

Manning, R., Wallis, I.R., 2005. Seed yields in canola (Brassica napus cv. Karoo) depend on the distance of plants from honeybee apiaries. Australian Journal of Experimental Agriculture 45, 1307-1313.

Mesa, L.A., Howlett, B.G., Grant, J.E., Didham, R.K., Ni, X., 2013. Changes in the relative abundance and movement of insect pollinators during the flowering cycle of Brassica rapa crops: implications for gene flow. Journal of Insect Science 13, 13-13.

Ollerton, J., Winfree, R., Tarrant, S., 2011. How many flowering plants are pollinated by animals? Oikos 120, 321-326.

Potts, S.G., Imperatriz-Fonseca, V., Ngo, H.T., Aizen, M.A., Biesmeijer, J.C., Breeze, T.D., Dicks, L.V., Garibaldi, L.A., Hill, R., Settele, J., Vanbergen, A.J., 2016. Safeguarding pollinators and their values to human well-being. Nature 540, 220-229.

Rader, R., Bartomeus, I., Garibaldi, L.A., Garratt, M.P.D., Howlett, B.G., Winfree, R., Cunningham, S.A., Mayfield, M.M., Arthur, A.D., Andersson, G.K.S., Bommarco, R., Brittain, C., Carvalheiro, L.G., Chacoff, N.P., Entling, M.H., Foully, B., Freitas, B.M., Gemmill-Herren, B., Ghazoul, J., Griffin, S.R., Gross, C.L., Herbertsson, L., Herzog, F., Hipólito, J., Jaggar, S., Jauker, F., Klein, A.-M., Kleijn, D., Krishnan, S., Lemos, C.Q., Lindström, S.A.M., Mandelik, Y., Monteiro, V.M., Nelson, W., Nilsson, L., Pattemore, D.E., de O. Pereira, N., Pisanty, G., Potts, S.G., Reemer, M., Rundlöf, M., Sheffield, C.S., Scheper, J., Schüepp, C., Smith, H.G., Stanley, D.A., Stout, J.C., Szentgyörgyi, H., Taki, H., Vergara, C.H., Viana, B.F., Woyciechowski, M., 2016. Non-bee insects are important contributors to global crop pollination. Proceedings of the National Academy of Sciences 113, 146-151. 
Rader, R., Howlett, B.G., Cunningham, S.A., Westcott, D.A., Edwards, W., 2012. Spatial and temporal variation in pollinator effectiveness: do unmanaged insects provide consistent pollination services to mass flowering crops? Journal of Applied Ecology 49, 126-134.

Rader, R., Howlett, B.G., Cunningham, S.A., Westcott, D.A., Newstrom-Lloyd, L.E., Walker, M.K., Teulon, D.A.J., Edwards, W., 2009. Alternative pollinator taxa are equally efficient but not as effective as the honeybee in a mass flowering crop. Journal of Applied Ecology 46, 1080-1087.

Rucker, R.R., Thurman, W.N., Burgett, M., 2012. Honey Bee Pollination Markets and the Internalization of Reciprocal Benefits. American Journal of Agricultural Economics 94, 956-977.

Sabbahi, R., de Oliveira, D., Marceau, J., 2005. Influence of Honey Bee (Hymenoptera: Apidae) Density on the Production of Canola (Crucifera: Brassicacae). Journal of Economic Entomology 98, 367-372.

Stanley, D., Gunning, D., Stout, J., 2013. Pollinators and pollination of oilseed rape crops (Brassica napus L.) in Ireland: ecological and economic incentives for pollinator conservation. Journal of Insect Conservation, 1-9.

Vanbergen, A.J., Initiative, t.I.P., 2013. Threats to an ecosystem service: pressures on pollinators. Frontiers in Ecology and the Environment 11, 251-259.

Williams, I.H., Martin, A.P., White, R.P., 1986. The pollination requirements of oilseed rape (Brassica napus L). Journal of Agricultural Science 106, 27-30.

Witter, S., Blochtein, B., Nunes-Silva, P., Pereira Tirelli, F., Brito Lisboa, B., Bremm, C., Lanzer, R., 2014. The bee community and its relationship to canola productivity in homogenous agricultural areas. 2014 12.

Woodcock, B.A., Bullock, J.M., McCracken, M., Chapman, R.E., Ball, S.L., Edwards, M.E., Nowakowski, M., Pywell, R.F., 2016. Spill-over of pest control and pollination services into arable crops. Agriculture, Ecosystems \& Environment 231, 15-23.

Woodcock, B.A., Edwards, M., Redhead, J., Meek, W.R., Nuttall, P., Falk, S., Nowakowski, M., Pywell, R.F., 2013. Crop flower visitation by honeybees, bumblebees and solitary bees: Behavioural differences and diversity responses to landscape. Agriculture, Ecosystems \& Environment 171, 1-8. 
Table 1. Statistical outcomes following generalised linear mixed effects models and likelihood ratio tests on the influence of distance from the field edge, survey round and their interaction on the abundance of different groups of flower visiting insect in oilseed rape fields. P values $<0.05$ are shown in bold.

\begin{tabular}{lllll}
\hline Pollinator group & Variable & $\mathrm{df}$ & $\chi^{2}$ & $\mathrm{P}\left(\chi^{2}\right)$ \\
\hline Honeybees & Distance & 3 & 40.21 & $\mathbf{< 0 . 0 0 1}$ \\
& Round & 2 & 17.29 & $\mathbf{< 0 . 0 0 1}$ \\
& Distance:Round & 6 & 5.04 & 0.54 \\
& & & & \\
Flies & Distance & 3 & 17.84 & $<\mathbf{0 . 0 0 1}$ \\
& Round & 2 & 82.93 & $<\mathbf{0 . 0 0 1}$ \\
& Distance:Round & 6 & 10.92 & 0.09 \\
Wild bees & Distance & 3 & 4.48 & 0.21 \\
& Round & 2 & 4.84 & 0.09 \\
& Distance:Round & 6 & 12.87 & $\mathbf{0 . 0 4 5}$ \\
\hline
\end{tabular}

Fig 1. The location of study fields including their experimental block and the number of honeybee hives that were introduced to the edge of each field.

Fig 2. The pollinator community observed visiting oilseed rape flowers following the introduction of 0 , 10 or 30 honeybee hives to the field edge.

Fig 3. The effects of honeybee hive number and distance into the field on the number of honeybees observed visiting oilseed rape flowers following the introduction of 0,10 or 30 honeybee hives to the field edge.

Fig 4. The effect of distance from the field edge on the number of standardised (Data point - mean / standard deviation) pollinator visitors observed on oilseed rape flowers. Mean $\pm \mathrm{SE}$.

Fig 5. The effect of survey round on the number of standardised (Data point - mean / standard deviation) pollinator visitors observed on oilseed rape flowers. Mean \pm SE. 
Fig 1

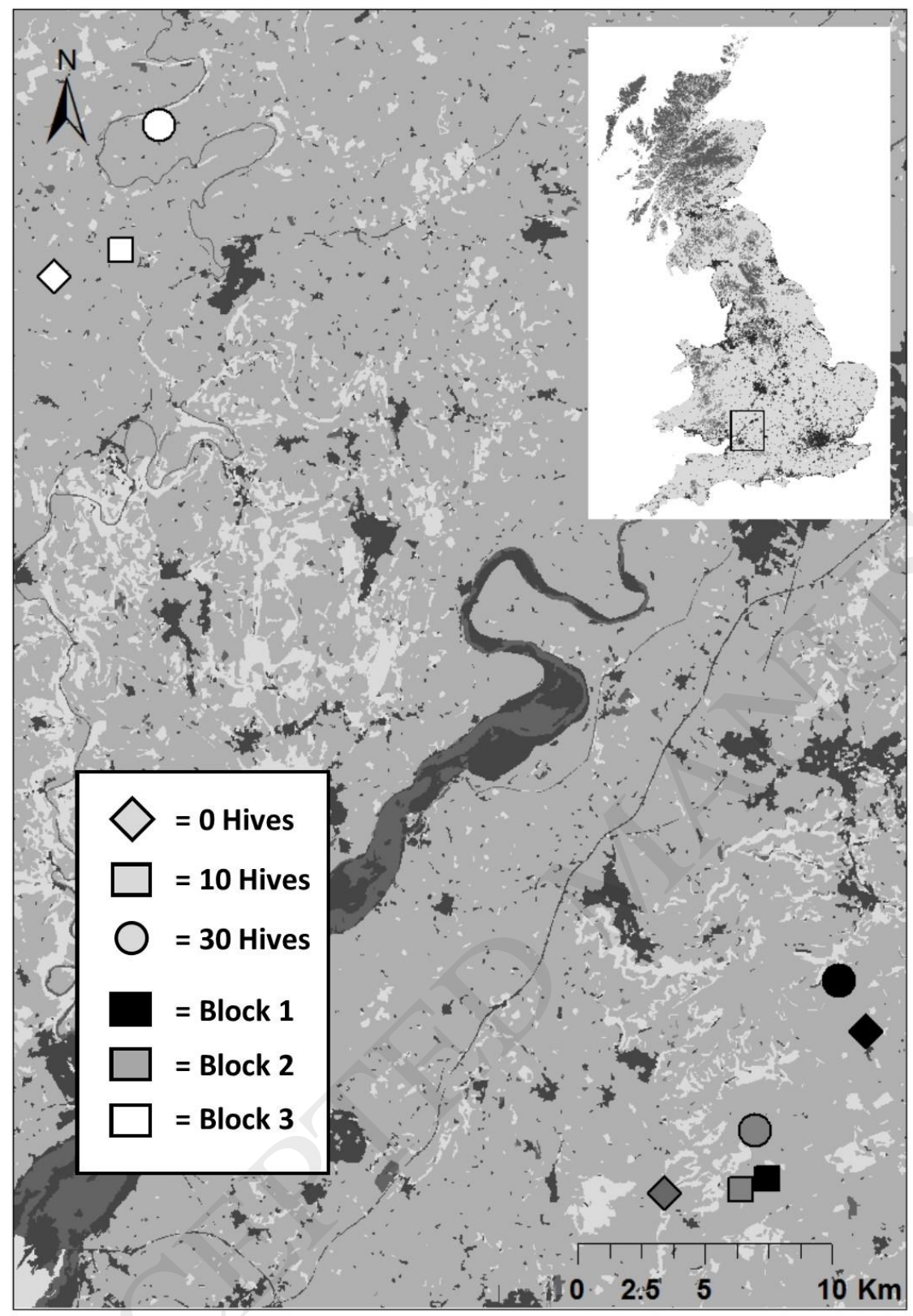


Fig 2

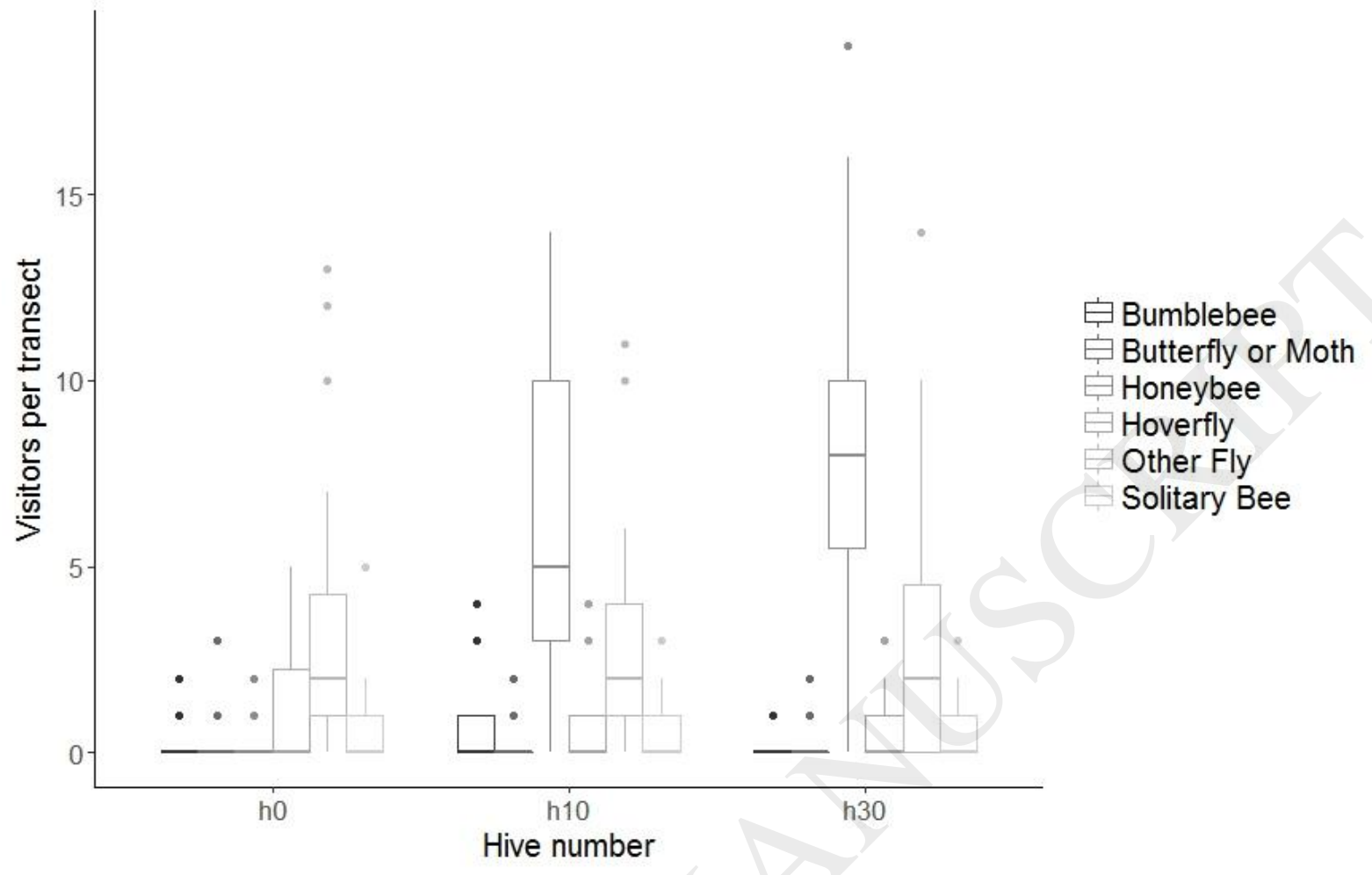

Fig 3

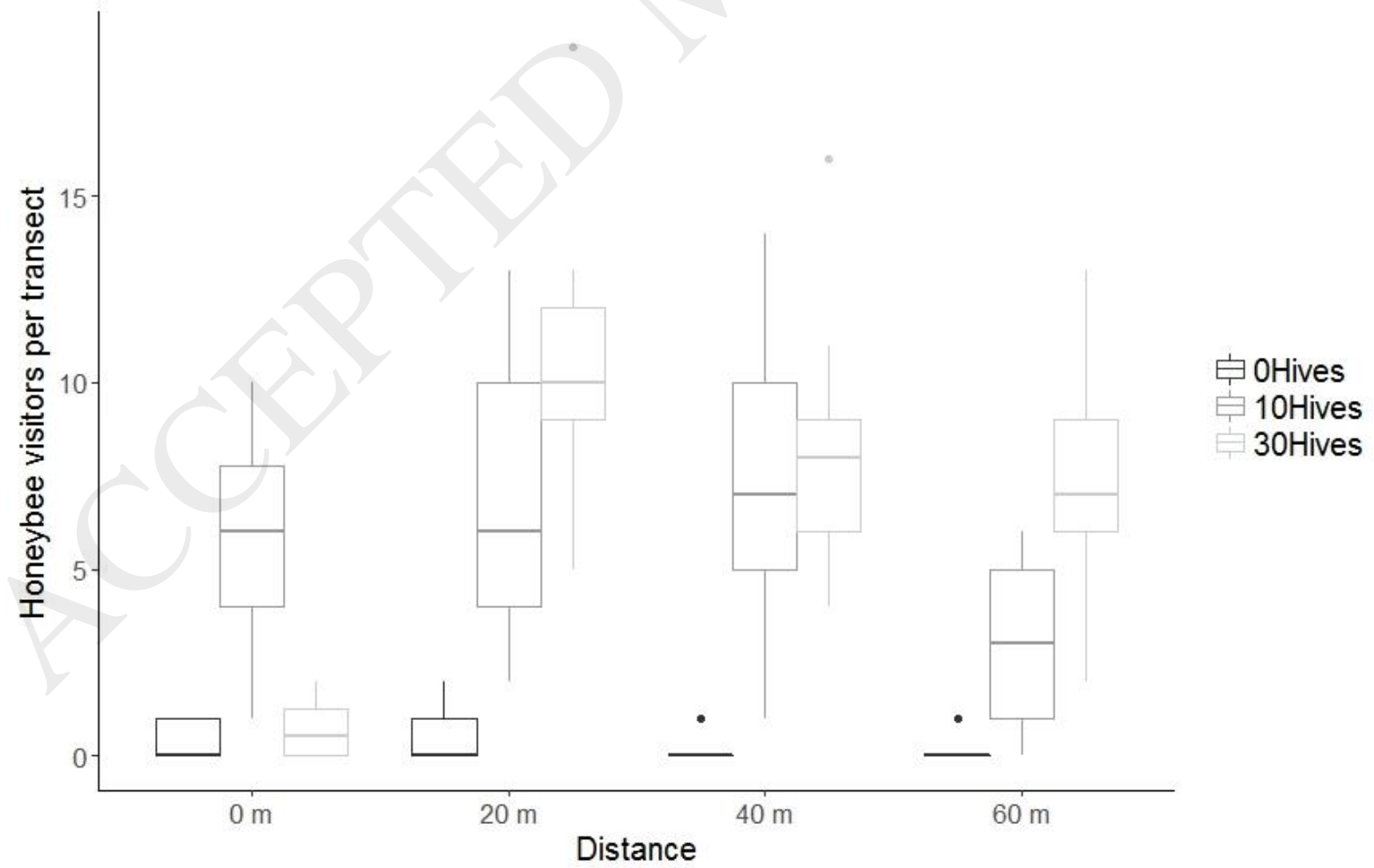


Fig 4

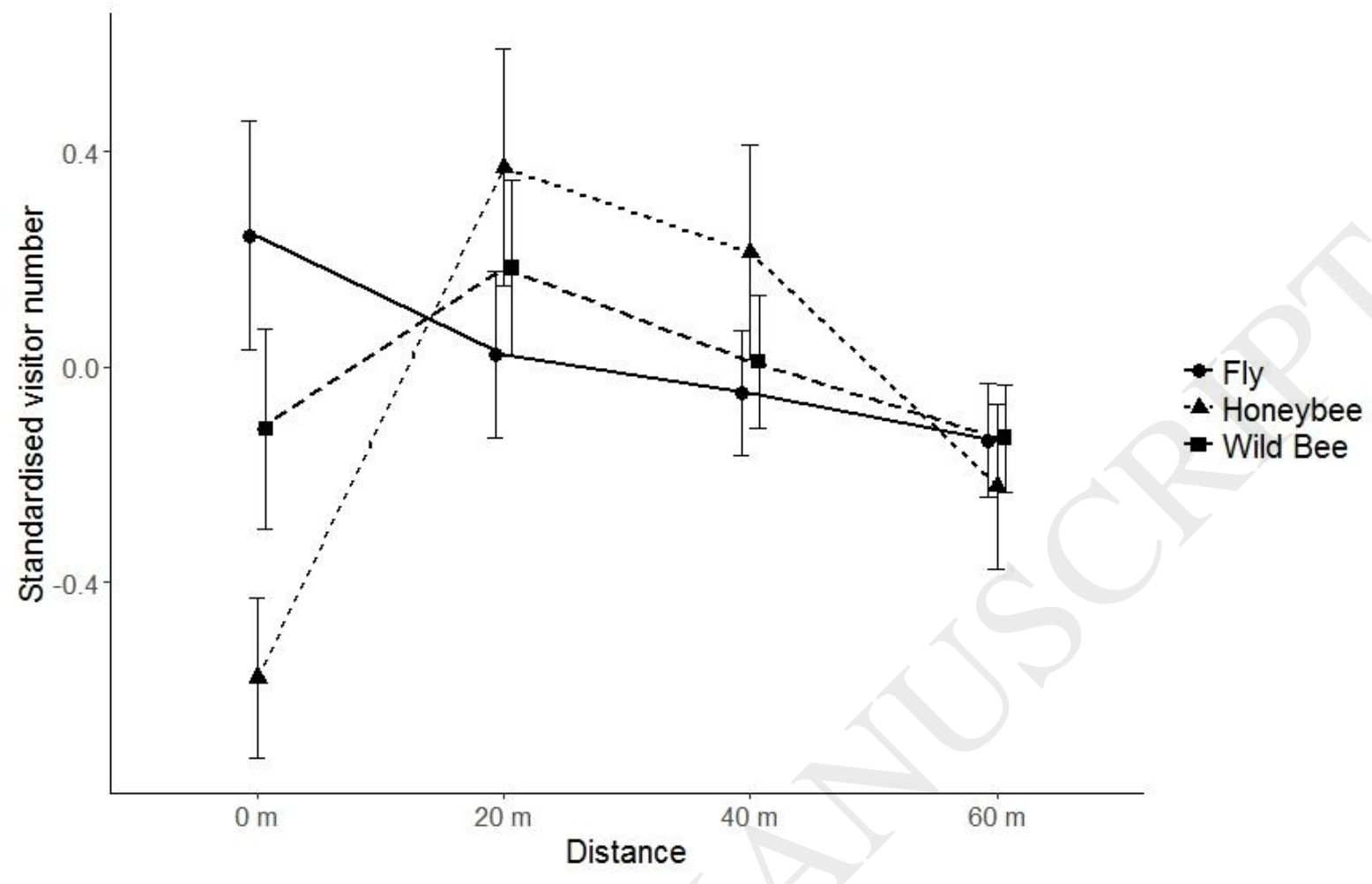

Fig 5

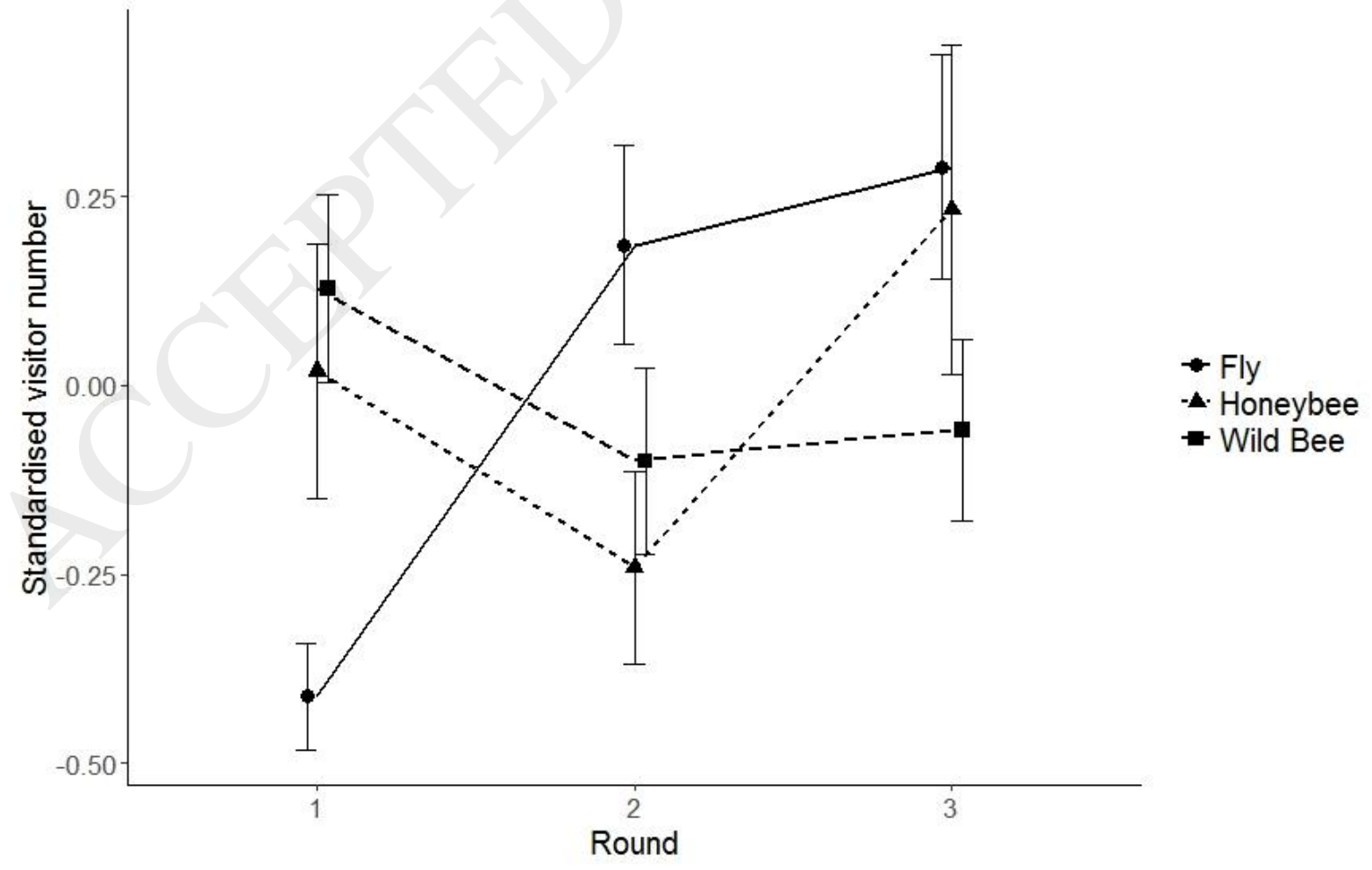


